\title{
Nilai-Nilai Spiritual yang Mencerminkan Budaya Organisasi Berdampak terhadap Peningkatan Kinerja Karyawan di Rumah Sakit YARSI
}

\author{
Irwan Kusnanda*, Rokiah Kusumapradja* \\ * Program Study Magister Administrasi Rumah Sakit, Universitas Esa Unggul \\ Email: irwan.is938@gmail.com; rokiah.kusumapradja@esaunggul.ac.id
}

\begin{abstract}
Performance appraisal for employee usually based on the job description that has been designed by organization. Therefore, the result of employee's performance appraisal will be considered based on employee's capability to complete all the tasks from their job description. The objective of this research is to analyze and identify the effect of compensation benefit, organizational commitment and organizational culture towards employee's performance in YARSI Hospital. The method of this research is using causality design method based on time dimension, one short study; the measurement towards dependent and independent variable at the same interval. The sampling technic in this research using Cluster random Sampling.Analyzed unit is data analysis using Regression. The result of this partial test revealed that employee's performance affected to organizational commitment, compensation benefit, organizational culture and the result of this simultaneous test showed that the most significant effect is compensation benefit. Surprisingly, Researcher finds that in YARSI Hospital spread over the spiritual values proved that all employee remain working hard even though the compensation benefit system has not been implemented at the finest condition.
\end{abstract}

Keywords: Compensation, Organizational Culture, Organizational Commitment, Employee Performance

\section{PENDAHULUAN}

Penilaian kinerja terhadap karyawan biasanya didasarkan pada job description yang telah disusun oleh organisasi. Dengan demikian, baik buruknya kinerja karyawan dilihat dari kemampuannya dalam melaksanakan tugas-tugas sesuai dengan pekerjaan yang menjadi tanggung jawabnya. Faktor yang tidak kalah penting yang mempengaruhi kinerja organisasi yaitu budaya organisasi.Budaya organisasi sangat berpengaruh terhadap perilaku para anggota organisasi. Hal ini karena sistem nilai dalam budaya organisasi dapat dijadikan acuan perilaku manusia dalam organisasi yang berorientasi pada pencapaian tujuan atau hasil kinerja yang ditetapkan.Sehingga jika budaya organisasi baik, maka tidak mengherankan jika anggota organisasi adalah orang-orang yang baik dan berkualitas pula. Dengan demikian budaya organisasi baik secara langsung maupun tidak langsung akan berpengaruh terhadap kinerja organisasi. ${ }^{1}$

Chong dan Leung Secara khusus menemukan bahwa skema kompensasi upah menghasilkan kinerja yang lebih tinggi dibandingkan dengan skema 
kompensasi bonus.Hal ini karena pembayaran gaji dengan adanya umpan balik kinerja memiliki penetapan tingkat tujuan yang sulit. Hasil penelitian menunjukkan bahwa pencapaian tujuan skema kompensasi bonus menghasilkan kinerja tugas yang lebih tinggi dibandingkan dengan skema kompensasi pembayaran yang cenderung lebih memotivasi. $^{2}$

Organisasi memberikan perhatian mereka terhadap organisasi, keberhasilan organisasi serta kemajuan yang berkelanjutan. Setiap karyawan dalam organisasi harus memiliki komitmen yang tinggi terhadap pencapaian misi, visi, dan tujuan organisasi. Dalam organisasi sektor publik, ikatan batin antara karyawan dengan organisasi dapat dibangun dari kesamaan misi, visi, dan tujuan organisasi, bukan sekedar ikatan kerja. Ikatan mereka untuk bekerja diinstansi pemerintah bukan sekedar gaji, namun lebih pada ikatan batin misalnya ingin menjadi abdi negara dan abdi masyarakat, status sosial, dan sebagainya. Sehingga bila setiap karyawan memiliki komitmen yang kuat untuk memberikan prestasi terbaik bagi negara dan pelayanan terbaik pada masyarakat, maka tentunya kinerja sektor publik akan meningkat. Peningkatan kinerja akan terjadi jika organisasi bergerak dari pendekatan berorientasi kontrol tradisional terhadap manajemen tenaga kerja yang terletak pada perintah yang telah ada, melaksanakan kontrol, dan "mencapai efisiensi dalam penerapan tenaga kerja". ${ }^{3}$

Penilaian kinerja secara lengkap dan obyektif masih perlu ditingkatkan di Rumah Sakit YARSI yang baru berjalan kurang dari dua tahun. Hal ini mengingat model penilaian kinerja masih dalam tahap penyempurnaan. Adapun rekap hasil performance appraisal karyawan secara umum kategori Star/unggul berjumlah 27 orang (19\%), kategori potential personadalah 101 orang $(71 \%)$, dan kategori Hardworker sebanyak 15 orang $(10 \%)$. Berdasarkan hal tersebut, dapat dilihat kategori Star masih di bawah 20\% dan yang terbanyak di kategori potential person. Hal tersebut karena karakter karyawan dalam budaya organisasi masih membawa kebiasaan lama yang perlu penyesuaian dengan budaya Rumah Sakit YARSI. Hal ini tentu saja tidak boleh dibiarkan terjadi berlarut-larut. Kesemua ini akan berdampak pada kinerja organisasi, dimana dalam era globalisasi saat ini menuntut kinerja organisasi yang tinggi untuk dapat bertahan hidup ditengah-tengah tingkat persaingan yang sangat ketat. Berkaitan dengan hal tersebut, maka perlu dilakukan penelitian untuk mengetahui faktor-faktor apa sajakah yang mempengaruhi kinerja karyawan.

Cahyono dan Suharto menyatakan motivasi intrinsik dan ekstrinsik serta budaya berpengaruh positif dan signifikan terhadap komitmen organisasi. ${ }^{4}$ Sedangkan Yuwalliatin menyatakan komitmen organisasi berhubungan positif dengan kinerja karyawan. ${ }^{5}$ Dengan mengidentifikasi dan meneliti berbagai faktor, diharapkan diperoleh gambaran tentang hal-hal yang berhubungan dengan peningkatan kinerja karyawan. Penelitian ini mencoba melakukan kajian faktorfaktor tersebut yaitu pengaruh kompensasi, budaya organisasi dan komitmen organisasi dalam meningkatkan kinerja karyawan di Rumah Sakit YARSI. Motivasi penelitian ini adalah adanya permasalahan yang didapat pada kategori komitmen organisasional yaitu kebijakan dari organisasi yang tidak sepenuhnya sampai kepada karyawan. Selanjutnya, pada kategori kompensasi tidak langsung, peneliti menemukan 3 dari 10 karyawan menyatakan tunjangan yang diberikan tidak sesuai dengan peraturan. Masalah Budaya organisasi yang ditemukan pada penelitian ini yaitu $80 \%$ karyawan masih membawa budaya kerja di tempat kerja sebelumnya.

Kinerja adalah suatu hasil kerja secara kualitas dan kuantitas yang dicapai 
seorang karyawan dalam melaksanakan tugasnya sesuai tanggung jawab dan kriteria yang telah ditentukan oleh perusahaan. Berdasarkan hasil penelitian yang dilakukan oleh Yuwalliatin yaitubudaya organisasi mampu memoderasi hubungan antara komitmen dengan kinerja karyawan. ${ }^{5}$ Tampubolon juga menyatakan bahwa budaya organisasi berpengaruh signifikan positif terhadap komitmen organisasional, kepuasan kerja dan kinerja karyawan. ${ }^{3}$ Dari uraian diatas maka terdapat pengaruh positif antara kinerja terhadap komitmen dan budaya organisasi.

Dessler mengklasifikasikan komitmen organisasional ke dalam tiga dimensi yaitu komitmen afektif, komitmen kontinuitas, dan komitmen normatif. Karyawan dengan komitmen afektif yang kuat tetap berada di organisasi karena mereka menginginkannya, komitmen kontinuitas yang kuat tetap ada karena mereka memerlukannya, dan komitmen normatif yang kuat tetap ada karena mereka merasa harus melakukannya. ${ }^{6}$ Berdasarkan hasil penelitian yang dilakukan oleh Suranta tahun 2007 dan Sulaiman tahun 2002, komitmen organisasional berhubungan positif dengan kinerja karyawan. ${ }^{7,8}$ Berdasarkan hal tersebut maka terdapat pengaruh positif antara komitmen terhadap kinerja.

Menurut Robbins, budaya organisasi mengacu pada sistem makna bersama yang dipegang oleh anggota, yang membedakan organisasi dari organisasi lain. ${ }^{9}$ Sistem makna bersama ini, setelah diteliti lebih dekat, merupakan serangkaian karakteristik kunci yang dihargai oleh organisasi. Suhana menemukanhubungan yang signifikan antara gaya kepemimpinan dan budaya organisasi, gaya kepemimpinan dan komitmen, dan antara budaya organisasi dan kinerja. ${ }^{10}$ Cahyono dan Suharto juga menyatakan dalam penelitiannya bahwa budaya organisasi mampu memoderasi hubungan antara gaya kepemimpinan dan kinerja karyawan. ${ }^{4}$
Berdasarkan hal tersebut maka terdapat pengaruh positif antara budaya organisasi terhadap kinerja.

Kompensasi dapat berbentuk intrinsik (internal) ataupun ekstrinsik (eksternal),dimana kompensasi intrinsik atau juga disebut kompensasi nonfinancial antara lain termasuk ujian yang didapatkan untuk penyelesian suatu proyek atau berhasil memenuhi suatu tujuan kinerja. Suhartono menemukan kompensasi berhubungan positif dengan kinerja karyawan dan budaya organisasi. ${ }^{11}$ Berdasarkan hal tersebut maka terdapat pengaruh positif antara kompensasi terhadap kinerja.

\section{METODE PENELITIAN}

Penelitian ini menggunakan teknik desain kausalitas berdasarkan dimensi waktu one short study, yaitu pengukuran terhadap variabel independen dan dependen yang dilakukan dalam waktu yang bersamaan. Teknik pengambilan sampel dalam penelitian ini menggunakan Cluster Random Sampling. Responden terdiri dari penunjang medis, tenaga medis, non medis, dan keperawatan. Data primer diperoleh dari penyebaran kuesioner yang ditujukan kepada karyawan Rumah Sakit yang berjumlah 117 orang, mencakup karyawan Medis dan Non Medis.

Pengujian Validitas Instrumen Penelitian dilakukan di RS Ananda Bekasi dengan jumlah responden 30 orang. Berdasarkan hasil uji validitas, 2 dari 9 indikator variabel Komitmen Organisasional dinyatakan tidak valid, Variabel Budaya Organisasi 4 dari 21 indikator dinyatakan tidak valid, Variabel Kompensasi tidak ada indikator yang tidak valid, dan Variabel Kinerja Karyawan 4 dari 15 indikator dinyatakan tidak valid. Indikator-indikator yang tidak valid tersebut dihilangkan, kemudian inidkatorindikator yang valid akan digunakan untuk analisis data selanjutnya.

Reliabilitas adalah alat untuk mengukur suatu kuesioner yang 
merupakan indikator dari suatu variabel. Kuesioner dinyatakan reliable jika $r$ hitung $>0.60$ dan sebaliknya jika $r$ hitung $<0.60$ berarti kuesioner tidak reliable. Cronbach's Alpha dari masing-masing variabel lebih besar dari 0.60 , sehingga dapat dikatakan bahwa seluruh kuesioner dalam penelitian ini reliable atau konsisten. Oleh karenanya, data dapat digunakan sebagai instrumen penelitian dan analisis lebih lanjut dapat dilakukan.

Analisis deskriptif menggunakan analisis indeks. Untuk mendapatkan kecenderungan jawaban responden terhadap masing-masing variabel, maka didasarkan pada nilai skor rata-rata (indeks) yang dikategorikan ke dalam rentang skor berdasarkan perhitungan three box method.

Batas atas rentang skor : $\left(\% \mathrm{~F}^{* 5}\right) / 5=$ $(115 * 5) / 5=115$

Batas bawah rentang skor : $\left(\% F^{* 1}\right) / 5$ $=(115 * 1) / 5=23$

Angka indeks yang dihasilkan menujukkan skor 23 - 115, dengan rentang sebesar 92. Dengan menggunakan three box method, maka rentang 92 dibagi menjadi tiga bagian, sehingga menghasilkan rentang untuk masingmasing bagian sebesar 30, dimana akan digunakan 2 penilaian sebagai daftar interpretasi indeks sebagai berikut:

\section{3-53 : Lemah / Rendah \\ 54-84 : Sedang/ Sedang \\ 85-115 : Kuat / Tinggi}

Selanjutnya untuk mengetahui pengaruh variabel bebas terhadap variabel tergangung maka digunakan metode statistic regresi linear. Hipotesis diuji pada derajat kemaknaan $<0.01$.

\section{HASIL DAN PEMBAHASAN}

\section{Karakteristik Responden}

Karakteristik responden dalam penelitian ini terdiri dari usia, pendidikan, masa kerja, dan jenis kelamin. Distribusi karakteristik tersebut disajikan pada Tabel 1 dibawah ini.

Tabel 1. Distribusi karakteristik responden

\begin{tabular}{lcc}
\hline Kategori & $\mathrm{N}$ & Persentase \\
\hline Usia & & \\
20-35 Tahun & 82 & $72 \%$ \\
35-50 Tahun & 33 & $28 \%$ \\
$\quad$ Total & 115 & $100 \%$ \\
Pendidikan & & \\
$\quad$ DIII & 26 & $23 \%$ \\
$\quad$ S1 & 89 & $77 \%$ \\
$\quad$ Total & 115 & $100 \%$ \\
Masa Kerja & & \\
$\quad$ 1 Tahun- 5 & 89 & $77 \%$ \\
Tahun & & \\
$\quad$ 5 Tahun - 10 & 26 & $23 \%$ \\
Tahun & & \\
$\quad$ Total & 115 & $100 \%$ \\
Jenis Kelamin & & \\
$\quad$ Laki-laki & 37 & $33 \%$ \\
$\quad$ Perempuan & 78 & $67 \%$ \\
$\quad$ Total & 115 & $100 \%$ \\
\hline
\end{tabular}

Pada Tabel 1, responden yang mendominasi yaitu pada usia 20-35 tahun sebanyak 82 orang $(72 \%)$, pendidikan tingkat S1 sebanyak 89 orang (77\%), masa kerja selama 1-5 tahun sebanyak 89 orang (77\%), dan jenis kelamin perempuan sebanyak 78 orang (67\%).

Nilai rata-rata dari 7 indikator variabel Komitmen Organisasional adalah 82 dan termasuk dalam kategori sedang. Artinya menurut responden organisasi memberikan yang terbaik untuk karyawan sehingga karyawan memiliki komitmen organisasional yang tinggi terhadap rumah sakit. Indeks tertinggi terdapat pada indikator dengan pertanyaan "Saya berpikir bahwa saya tidak dapat dengan mudah menjadi terikat pada organisasi lain, seperti rasa terikat terhadap organisasi saya saat ini" yang memiliki nilai indeks sebesar 100.8. Hal tersebut 
menunjukkan bahwa karyawan mampu berkomitmen tinggi terhadap rumah sakit.

Nilai rata-rata dari 17 indikator variabel Budaya Organisasi adalah 82 dan termasuk dalam kategori Sedang. Artinya menurut responden budaya organisasi di rumah sakit sudah cukup baik. Indeks tertinggi terdapat pada indikator dengan pertanyaan "Adanya kekhasan sikap karyawan didalam pelayanan kepada konsumen misalnya: keramahan, ketepatan waktu dalam pelayanan" yang memiliki nilai indeks sebesar 90.6. Hal tersebut menunjukkan bahwa karyawan menyatakan adanya kekhasan dalam pelayanan rumah sakit.

Nilai rata-rata dari 8 variabel Kompensasi adalah 79 dan termasuk dalam kategori sedang. Artinya menurut responden sistem kompensasi di rumah sakit sudah cukup baik. Indeks tertinggi terdapat pada indikator dengan pertanyaan "Perusahaan mempunyai fasilitas kesehatan, rumah ibadah, kantin dan fasilitas-fasilitas fisik lainnya untuk karyawan" yang memiliki nilai indeks sebesar 92.2. Hal tersebut menunjukkan bahwa karyawan menyatakan rumah sakit sudah memberikan fasilitas yang lengkap dan terbaik untuk karyawan.

Nilai rata-rata untuk variabel Kinerja Karyawan adalah 89 dan termasuk dalam kategori tinggi. Artinya menurut responden kinerja di rumah sakit sudah sangat baik. Indeks tertinggi terdapat pada indikator dengan pertanyaan "Kesungguhan saya dalam melaksanakan tanggung jawab" yang memiliki nilai indeks sebesar 94.4. Hal tersebut menunjukkan kesungguhan karyawan dalam melaksanakan tugas sudah sangat baik.

\section{Pengaruh variabel Komitmen Organisasional, Budaya Organisasi dan kompensasi terhadap kinerja karyawan}

Tabel 2. Hasil uji simultan

\begin{tabular}{|c|c|c|c|c|c|}
\hline \multirow[t]{2}{*}{ Model } & \multicolumn{2}{|c|}{$\begin{array}{c}\text { Unstandardized } \\
\text { Coefficients }\end{array}$} & \multirow{2}{*}{$\begin{array}{c}\text { Standardized } \\
\text { CoefficientsBeta }\end{array}$} & \multirow[t]{2}{*}{$\mathrm{t}$} & \multirow[t]{2}{*}{ Sig. } \\
\hline & B & Std. Error & & & \\
\hline (Constant) & 24.753 & 2.979 & & 8.308 & .000 \\
\hline Komitmen Organisasional & .138 & .141 & .090 & .978 & .330 \\
\hline Budaya Organisasi & .006 & .057 & .012 & .109 & .913 \\
\hline Kompensasi & .521 & .102 & .554 & 5.116 & .000 \\
\hline
\end{tabular}

Uji asumsi model linear menunjukkan bahwa nilai t hitung sebesar 8.199 (>1.983) dengan taraf signifikans $0.000 \quad(<0.05)$, dapat dikatakan bahwa kompensasi berpengaruh positif dan signifikan terhadap kinerja karyawan.

Tabel 2 menunjukkan hasil uji simultan antara variabel komitmen organisasional, budaya organisasi, dan kompensasi terhadap kinerja karyawan.
Berdasarkan tabel, hanya variabel kompensasi yang memiliki nilai signifikansi kurang dari 0.05 dengan nilai $\mathrm{t}$ hitung sebesar 5.116 (>1.983). sehingga dapat disimpulkan bahwa secara simultan, hanya variabel kompensasi yang berpengaruh secara signifikan terhadap kinerja karyawan di Rumah Sakit YASR Jakarta.

\section{Hasil Uji Determinasi}

Tabel 3. Hasil uji determinasi

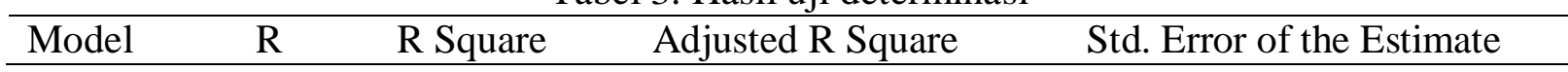




\begin{tabular}{l}
\hline $1.616^{\mathrm{a}} .379$ \\
a. Predictors: (Constant), Kompensasi, Kom \\
Pada Tabel 3, diketahui nilai \\
koefisien determinasi atau R Square adalah \\
sebesar 0.362 atau sama dengan $36.2 \%$. \\
Angka tersebut menunjukkan komitmen \\
organisasional (X1), budaya organisasi \\
(X2), dan kompensasi (X3) secara \\
simultan berpengaruh terhadap variabel \\
kinerja karyawan (Y) sebesar $36.2 \%$, \\
sedangkan sisanya 63.8 \% dipengaruhi \\
oleh variabel lain yang tidak diteliti oleh \\
penulis. \\
Pengaruh yang Signifikan dari \\
Komitmen Organisasional terhadap \\
Kinerja Karyawan \\
Komitmen organisasional adalah
\end{tabular}
sikap individu terhadap organisasi tempat mereka bekerja. Sikap tersebut adalah sikap konsen individu dimana mereka terlibat dengan organisasi dan tertarik untuk mempertahankan organisasi tersebut. Individu yang memiliki komitmen organisasional ditandai dengan munculnya keinginan kuat untuk tetap menjadi anggota organisasi tertentu, keinginan untuk berusaha keras sesuai dengan keinginan organisasi, dan penerimaan nilai-nilai serta tujuan organisasi. $^{12}$

Hasil penelitian yang dilakukan penulis menunjukkan bahwa komitmen organisasi berpengaruh positif dan signifikan terhadap kinerja karyawan. Hal ini sejalan dengan hasil penelitianSuranta tahun 2002 dan Sulaiman tahun 2002, yaitu komitmen organisasional berhubungan positif dengan kinerja karyawan. ${ }^{(7),(8)}$ Ini berarti bahwa komitmen organisasional yang dimiliki oleh tiap karyawan Rumah Sakit YARSI memberikan kontribusi yang tinggi terhadap pencapaian kinerja organisasi. Semakin baik komitmen organisasional maka kinerja yang dihasilkan juga akan semakin meningkat. Hal ini konsisten dengan teori yang dinyatakan oleh
.362

3.818

men Organisasional, Budaya

Dessleryang mengemukakan bahwa komitmen organisasi yang kuat akan mendorong para individu untuk berusaha lebih keras dalam mencapai tujuan organisasi. ${ }^{6}$ Oleh karenanya komitmen yang tinggi menjadikan individu lebih mementingkan organisasi dari pada kepentingan pribadi dan berusaha menjadikan organisasi menjadi lebih baik lagi.

Pengaruh yang Signifikan dari Budaya Organisasi terhadap Kinerja
Karyawan

Teori Budaya Organisasi menurut Robbins, Judge, Odendaal, dan Roodt tahun 2009 adalah sebagai berikut: "Organisasi mengacu pada sistem makna bersama yang dipegang oleh anggota, yang membedakan organisasi dari organisasi lain. Sistem makna bersama ini, setelah diteliti lebih dekat, merupakan serangkaian karakteristik kunci yang dihargai oleh organisasi". ${ }^{13}$ Hasil penelitian yang dilakukan penulis menunjukkan bahwa budaya organisasi berpengaruh positif dan signifikan terhadap kinerja karyawan. Hasil penelitian ini konsisten dengan teori yang dinyatakan oleh Robbins tahun 2007, yang menyatakan bahwa budaya organisasi yang baik menjadi penentu atau determinan dari: (1) tata kelola perusahaan yang baik, (2) terbentuk dan berkembangnya manajemen profesional, (3) kuatnya komitmen tanggung jawab sosial dari instansi terhadap lingkungannya, dan (4) semangat untuk menjaga keunggulan instansi. ${ }^{14}$

Hasil penelitian ini sejalan dengan penelitian yang dilakukan oleh Primanda tahun 2008 dan Fajrina tahun 2009 yang menyatakan bahwa budaya organisasi berpengaruh positif terhadap kinerja organisasi. $^{15,16}$ Penelitian ini juga didukung oleh Suhana yang menyimpulkan bahwa hubungan yang signifikan ditemukan antara gaya 
kepemimpinan dengan budaya organisasi, gaya kepemimpinan dengan komitmen, dan antara budaya organisasi dengan kinerja. ${ }^{10}$ Cahyono dan Suharto juga mengungkapkan hal yang serupa yakni budaya organisasi mampu memoderasi hubungan antara gaya kepemimpinan dan kinerja karyawan. ${ }^{4}$ Berdasarkan penelitian yang dilakukan oleh Abdullah dan Arisanti menunjukkan hasil analisis data yang sama dengan peneitian ini yaitu pengaruh budaya organisasi mempunyai hubungan yang positif dan signifikan terhadap kinerja organisasi. ${ }^{17}$

RS Yarsi yang baru berjalan satu tahun masih terus beradaptasi dengan budaya organisasi yang baru karena budaya organisasi merupakan faktor yang paling kritis dalam organisasi. Efektivitas organisasi dapat ditingkatkan dengan menciptakan budaya yang kuat, yang dapat digunakan untuk mencapai tujuan organisasi. Organisasi yang berbudaya kuat akan memiliki ciri khas tertentu sehingga dapat memberikan daya tarik bagi individu untuk bergabung. Suatu budaya yang kuat merupakan perangkat yang sangat bermanfaat untuk mengarahkan perilaku karena membantu karyawan untuk melakukan pekerjaan dengan lebih baik.Oleh karena itu, setiap karyawan perlu memahami budaya dan bagaimana mengimplementasikannya. Budaya organisasi berfungsi sebagai sistem perekat. Budaya organisasijuga digunakan sebagai acuan dalam berperilaku di dalam perusahaan untuk mencapai tujuan perusahaan yang telah ditetapkan, sehingga secara langsung ataupun tidak langsung memiliki pengaruh terhadap kinerja organisasi.

\section{Pengaruh yang Signifikan dari Kompensasi terhadap Kinerja Karyawan}

Menurut Dessler kompensasi dapat berbentuk intrinsik (internal) atau ekstrinsik (eksternal). Kompensasi intrinsik atau juga disebut kompensasi non finansial salah satunya adalah ujian yang didapatkan untuk penyelesaian suatu proyek atau berhasil memenuhi suatu tujuan kinerja. Efek psikologis lain dari kompensasijuga merupakan gambaran dari jenis imbalan intrinsik. Kompensasi ekstrinsik yang juga disebut sebagai kompensasi finansial bersifat terukur, yang memiliki bentuk imbalan moneter maupun non moneter. Komponen terukur dari program kompensasi ekstrinsik ada dua jenis yaitu kompensasi yang bersifat langsung (umumnya berupa gaji pokok dan gaji variabel) dan kompensasi tidak langsung berupa tunjangan-tunjangan. ${ }^{6}$

Menurut penelitian Nitisemito pengaruh kompensasi terhadap karyawan sangatlah besar. ${ }^{18}$ Semangat kerja yang tinggi, keresahan, dan loyalitas karyawan banyak dipengaruhi oleh besarnya kompensasi. Pada umumnya, pemogokan kerja yang sering terjadi di negara kita ini, sebagian besar disebabkan karena masalah upah. Pembayaran kompensasi berdasarkan keterampilan, sebenarnya dalam kondisi tertentu dapat meningkatkan kinerja karyawan, disamping dapat pula membuat karyawan frustasi. Bagi karyawan yang memang memiliki keterampilan yang dapat diandalkan, maka pemberian kompensasi berdasarkan keterampilan akan dapat meningkatkan kinerja, sebaliknya bagi karyawan yang tidak memiliki keterampilan dan tidak mempunyai kemampuan untuk meningkatkan keterampilannya, maka sistem pemberian kompensasi ini dapat mengakibatkan frustasi.

Jika dikaitkan dengan teori pengharapan, maka pemberian kompensasi berdasarkan keterampilan akan memotivasi karyawan, sebab dalam teori pengharapan dikatakan bahwa seorang karyawan akan termotivasi untuk mengerahkan usahanya dengan lebih baik lagi apabila karyawan merasa yakin, bahwa usahanya akan menghasilkan penilaian prestasi yang baik. Penilaian yang baik akan diwujudkan dengan 
penghargaan dari perusahaan seperti pemberian bonus, peningkatan gaji atau promosi, sehingga penghargaan itu dapat memuaskan karyawan. Di Rumah Sakit YARSI sistem Kompensasi sudah cukup baik. Hal ini terlihat dari jawaban karyawan dalam analisa deskriptif. Selain kompensasi finansial, kompensasi non finansial di Rumah Sakit Yarsi juga sangat baik dimana karyawan menyatakan puas dengan fasilitas yang diberikan sehingga dapat menunjang kinerja karyawan.

\section{Pengaruh yang Signifikan dari Komitmen Organisasional, Budaya Organisasi, dan Kompensasi terhadap Kinerja Karyawan}

Berdasarkan hasil uji regresi linier berganda, diketahui bahwa baik diuji bersama-sama maupun per variabel, kompensasi mempunyai pengaruh signifikan terhadap kinerja. Hal ini bisa dipahami karena sebagian besar responden menyatakan kepuasannya atas kompensasi yang telah diberikan perusahaan. Hal ini bisa dibuktikan dari distribusi frekuensi dimana hampir seluruh jawaban responden mengarah pada rasa puas atas kompensasi dan mengarah pada kesetiaan yang tinggi pada organisasi. Kemudian, jika ditinjau dari segi kebijakan kompensasi yang diterapkan rumah sakit, nampaknya sangat baik sehingga karyawan merasa kerasan bekerja di perusahaan ini, atau dengan kata lain karyawan mempunyai tingkat kesetian yang cukup tinggi, karena merasa kompensasi yang mereka terima sesuai dengan yang diharapkan. Hal ini sesuai dengan apa yang dikemukakan oleh Buchananbahwa salah satu upaya untuk meningkatkan komitmen karyawan adalah dengan cara memenuhi apa yang menjadi harapan Karyawan. ${ }^{19}$ Sementara menurut Steers dan Potter, salah satu cara meningkatkan kepuasan karyawan adalah dengan memeberikan kompensasi yang memuaskan. ${ }^{20}$ Hasil penelitian yang pernah dilakukan Steers tahun 1997 menunjukkan bahwa penghargaan organisasi sebagai bagian dari karakteristik pekerjaan mempunyai hubungan yang signifikan dengan komitmen karyawan pada organisasi yang salah satunya diwujudkan dalam bentuk kesetiaaan karyawan pada organisasiSteers (1977). ${ }^{12}$ Begitu pula dalam penelitian ini nampaknya tidak jauh berbeda dengan hasil penelitian Steers, walaupun ada sedikit perbedaaan dalam menentukan variabel.

Menurut Robbins tahun 2007, kompensasi berdasarkan keterampilan sesuai dengan teori ERG (Existence, Relatedness and Growth theory) dari Alderfer, sebab sistem pembayaran ini dapat mendorong karyawan untuk belajar serta meningkatkan dan memelihara keterampilannya. ${ }^{21} \mathrm{Hal}$ ini dapat diartikan, bahwa bagi karyawan yang ingin memenuhi kebutuhannya dengan lebih baik, maka pemberian kompensasi berdasarkan keterampilan akan menjadi pendorong baginya untuk lebih meningkatkan keterampilan, agar memperoleh kompensasi yang lebih tinggi. Dengan demikian, kebutuhannya akan terpenuhi. Jika dikaitkan dengan teori kebutuhan untuk berprestasi (need for achievement theory), pemberian kompensasi berdasarkan keterampilan juga sesuai, sebab sistem pembayaran kompensasi ini dapat mendorong karyawan untuk bekerja lebih efisien, mau mempelajari keterampilan yang baru atau berusaha meningkatkan keterampilannya, sehingga siap menghadapi tantangan baru. Hal ini cukup jelas, sebab mempelajari keterampilan baru merupakan tantangan tersendiri bagi seseorang yang ingin maju. Apabila tantangan ini dapat dilampaui, maka akan timbul rasa bangga bagi yang bersangkutan. Kebanggaan bukan hanya karena prestasi yang meningkat, tetapi juga karena penghargaan yang diterima juga meningkat dan memuaskan bagi dirinya.Dalam kaitannya dengan teori penguatan (reinforcement theory), pembayaran kompensasi berdasarkan 
keterampilan akan mendorong karyawan untuk belajar secara kontinyu, mengembangkan keterampilannya, dan dapat bekerja sama dengan anggota lain dalam perusahaan. Semakin berkembang keterampilan yang dimiliki, maka akan semakin besar pula kompensasi yang akan diterimanya.

$$
\text { Pada kenyataannya,Rumah Sakit }
$$

YARSI sudah cukup baik dalam menghargai keterampilan dan kemampuan seseorang, sehingga sering dijumpai pemberian kompensasi didasarkan bukan pada senioritas akan tetapi pada kemampuan seorang karyawan untuk mengembangkan keterampilan yang dimilikinya. Kondisi ini tidak dapat mengakibatkan karyawan menjadi apatis. Karyawan akan termotivasi untuk meningkatkan kinerjanya, sebab peningkatan keterampilan diimbangi dengan peningkatan kompensasi dan kompensasi akan naik dengan meningkatkan keterampilan. Sistem kompensasi yang sudah baik di Rumah Sakit YARSI akan meningkatkan produktivitas/kinerja maupun kualitas pelayanannya, sehingga dapat menghasilkan produk yang berkualitas dengan harga pelayanan yang kompetitif.

Rumah Sakit YARSI yang menjunjung tinggi nilai Spiritual telah membuktikan bahwa karyawan dapat memberikan kinerja terbaiknya walaupun sistem kompensasi belum berjalan secara optimal.Dalam pandangan Islam, bekerja merupakan satu kesatuan yang tidak terpisahkan, mulai dari niat bekerja yaitu tidak hanya mencari kelimpahan meteri di dunia tetapi juga mencari pahala untuk di akhirat nanti. Ketika niat bekerja adalah ibadah maka di dalamnya sudah terkandung dua tujuan yaitu memenuhi kebutuhan jasmani dan kebutuhan rohani atau kebutuhan materiil dan nonmateriil. Dengan demikian, karena tujuan bekerja tidak semata-mata mencari kelimpahan materi maka effort yang dikeluarkan tidak hanya dalam bentuk kekuatan fisik tetapi juga kekuatan non fisik (doa). Dengan demikian, output dari kerja adalah sikap kerja yang terbingkai dengan rasa tawakal. Artinya, ketika seorang individu sudah bekerja dengan seluruh kemampuannya, kemudian hasil dari kerja tidak seluruhnya sesuai dengan harapannya maka ia akan tetap menerima hasil kerja dengan rasa syukur. Ia tidak akan memelihara rasa kecewa yang berkepanjangan, karena ia tahu persis bahwa manusia hanya wajib berusaha dan Allahlah yang menentukan hasilnya. Selain itu, pemaknaan atas nilainilai ajaran Islam bahwa kalau seseorang bersyukur atas nikmat yang diberikan Allah maka Allah akan menambahkan rasa nikmatnya lebih besar lagi. Nilai-nilai spiritual itu memberikan motivasi untuk senantiasa bekerja, berusaha dan mensyukuri hasilnya. Dengan demikian, hasil dari penilaian kerja akan disikapi oleh seorang Muslim dengan sikap kerja yang positif (perasaan puas).

\section{KESIMPULAN}

Berdasarkan hasil penelitian dan pembahasannya, maka peneliti dapat menarik suatu kesimpulan bahwa hasil uji pengaruh secara simultan antara komitmen organisasiaonal, budaya organisasi dan kompensasi terhadap kinerja diperoleh bahwa hanya variabel kompensasi yang mempunyai pengaruh signifikan terhadap kinerja karyawan. Hal ini berarti dengan sistem kompensasi di Rumah Sakit YARSI maka dengan mudah Rumah Sakit untuk meningkatkan produktivitas/kinerja maupun kualitas pelayanannya, sehingga dapat menghasilkan produk yang berkualitas dengan harga pelayanan yang kompetitif.

Saran dari peneliti, untuk meningkatkan budaya organisasi dan komitmen organisasional terhadap institusi, sebaiknya manajemen melakukan sosialisasi mengenai kaidah-kaidah budayasesuai dengan visi dan misi rumah sakit secara berkelanjutan. Selain itu, komunikasi yang efektif juga perlu 
dilakukan agar seluruh karyawan mampu membangun pribadi yang unggul sebagai bagian dari organisasi ini. Pemberian kompensasi dengan memberlakukan reward dan funishment secara optimal, menetapkan pola karir serta penyesuain beban kerja terhadap kompensasi sebagai implikasi manajemen juga sebaiknya dilakukan untuk lebih meningkatkan kinerja karyawan.

\section{UCAPAN TERIMAKASIH}

Penulis menyampaikan penghargaan setinggi-tingginya dan terima kasih kepada Dr. Rokiah Kusumaprdja, SK.,MHA selaku Ketua Program Studi Magister Administrasi Rumah Sakit sekaligus sebagai pembimbing I dan Dr. Rina Anindita, SE., MM sebagai pembimbing II, yang telah banyak memberi dukungan, bantuan dan motivasi sejak perkuliahan dimulai sampai penulisan tesis ini.

\section{DAFTAR PUSTAKA}

1. Aisyah S, Karmizi, Savitri E. Pengaruh good governance, gaya kepemimpinan, komitmen organisasi, dan budaya organisasi terhadap kinerja Pemerintah Daerah. JOM FEKON 2014; 1: 1-16.

2. Chong V, Leung ST. The effect of feedback, assigned goal levels and compensation schemes on task performance. Asian Rev Account 2018; 26: 314-335.

3. Tampubolon BD. Analisis faktor gaya kepemimpinan dan faktor etos kerja terhadap kinerja pegawai pada organisasi yang telah menerapkan SNI 19-9001-2001. J Stand 2007; 9: 106115.

4. Cahyono B, Suharto. Pengaruh budaya organisasi, kepemimpinan dan motivasi kerja terhadap kinerja sumber daya manusia, di Sekretariat DPRD Propinsi Jawa Tengah. J Ris Bisnis Indones 2005; 1: 13-30.

5. Yuwalliatin S. Pengaruh budaya organisasi, motivasi, dan komitmen terhadap kinerja serta pengaruhnya terhadap keunggulan kompetitif. $J$ Ekon dan Bisnis 2006; 7: 241-256.

6. Dessler G. Manajemen sumber daya manusia. 7th ed. Jakarta: PT. Prenhallindo, 1997.

7. Suranta S. Dampak motivasi karyawan pada hubungan antara gaya kepemimpinan dengan kinerja karyawan perusahaan bisnis. $J$ Empirika 2002; 15: 116-138.

8. Sulaiman AM. Is it really a mediating construct? the mediating role of organizational commitment in work climate-performance relationship. $J$ Manag Dev 2002; 21: 170-183.

9. Robbins SP. Perilaku organisasi. 14th ed. New Jersey: Pearson Education, 2009.

10. Suhana. Relationship analysis of leadership style, HRM practices,organizational culture, commitment and performance (study in people crediting bank (BPR) in Central Java). Manaj Usahaw Indones 2007; 36: 47-53.

11. Suhartono I. Manajemen kinerja pada perusahaan bisnis dari manajemen kinerja tradisional ke manajemen kinerja baru. J Ilm Among Makarti 2010; 3: 105-118.

12. Steers RM. Antecedents and outcomes of organizational commitment. Adm Sci $Q 1977$; 22: 46-56.

13. Robbins SP, Judge TA, Odendaal A, et al. Organisational behaviour: global and Southern African perspectives. 2nd ed. Cape Town: Pearson Education South Africa Ltd, 2009.

14. Robbins SP. Perilaku Organisasi. 10th ed. Klaten: PT. Macanan Jaya emerlang, 2007.

15. Primanda R. Pengaruh budaya organisasi, locus of control dan penerapan sistem informasi terhadap kinerja aparat unit-Unit pelayanan publik. Universitas Muhammadiyah Surakarta, 2008. 
16. Fajrina DSF. Analisis pengaruh kepemimpinan, disiplin kerja dan budaya organisasi terhadap kinerja pegawai Badan Perencanaan Pembangunan Daerah Kota Magelang. Universitas Diponegoro, 2009.

17. Abdullah, Arisanti H. Pengaruh budaya organisasi, komitmen organisasi dan akuntabilitas publik terhadap kinerja organisasi. J Ekon dan Bisnis; 9.

18. Nitisemito AS. Manajemen personalia. Rev. Jakarta: Ghalia Indonesia, 2014.

19. Buchanan JM. The limit of liberty: between anarchy and leviathan. Chicago: university of Chicago Press, 1975.

20. Steers RM, Porter LW. Motivation and work behavior. 3rd ed. New York: McGraw-Hill, 1983.

21. Robbins SP. Perilaku organisasi: konsep, kontroversi, aplikasi. 8th ed. Jakarta: PT. Prenhallindo, 2001. 